\title{
ANALYSIS OF VEHICLE MOVING PARAMETERS IN VARIOUS ROAD CONDITIONS
}

\author{
Rafał Jurecki*, Tomasz Stańczyk \\ Faculty of Mechatronics and Mechanical Engineering, Kielce University of Technology, Kielce, Poland \\ *E-mail of corresponding author: rjurecki@tu.kielce.pl
}

\section{Resume}

The safety of road users is one of the priority issues raised by those involved in vehicle design, latest passive and active safety systems, traffic organization or driver education. Nowadays, an important road safety problem is the behaviour of drivers in emergency situations. In order to measurably estimate the driving quality, parameters such as velocity, acceleration, the way and frequency of using the control pedals are quite often used. This article describes how to assess driver's behaviour based on measurements taken on the road. The frequency of different acceleration ranges during the vehicle drive was determined based on the results obtained. For the arbitrarily adopted acceleration range of $-0.5-0.5 \mathrm{~m} / \mathrm{s}^{2}$, the driver's working time was over 77 percent on average, with the difference varying significantly between different route sections. Similarly, the study compares the driving times for other ranges of acceleration.

\section{Article info}

Received 18 September 2020

Accepted 3 November 2020

Online 24 March 2021

\section{Keywords:}

safety, driver behaviour, acceleration, data acquisition system, acceleration sensors

ISSN 1335-4205 (print version)

ISSN 2585-7878 (online version)

\section{Introduction}

Research on drivers regarding improvement of the road safety is performed in many research centres. Over the years, there have been various references to the way the driver's behaviour is defined and modelled. Due to a large number of factors that can determine the way drivers behave and drive, this topic is still relevant. This is even more important since nowadays driving is a quite common activity. At the same time, e impact of the road traffic, which generates many threats in the present world, makes the topic related to attempts to increase safety in this area very important. Many efforts are being made to implement tests and analyses to detect certain driver behaviour relationships that may have a direct impact on the road safety. Three methodological aspects are identified in [1] as being important in analysis of the road accidents. They covered reliability of accident predictors, time period for accidents used as dependent variable and culpability for accidents. To be able to predict the ability of drivers to drive safely, tests were performed in a driving simulator to determine the visual sensitivity, defined as the ability to respond quickly to various visual stimuli [2].

Therefore, there are many publications in which the driving process is analysed. These tests concern both attempts to determine the driver's profile, personality traits and the ability (aptitude) to drive. Many of them refer to three main aspects of the driving efficiency, namely physical and mental fitness, as well as knowledge, skills and attitude of the driver.

The dominant aspect of the tests is assessment of the mental fitness while driving. They analyse the mental, intellectual and personality traits of drivers. This test range is described in publications where the following are tested: driver response time [3-7], driver perception quality, stereoscopic and stereometric vision. The mental acuity, vision after dark and glare sensitivity, fatigue, eye-hand coordination [8-10] is particularly crucial in the case of elderly people. Very important parameters determining the driver is experience, ability to assess the velocity of vehicles in motion, selected memory features. The listed features of drivers and their mode of operation are tested in various environments, both real (standard road or test section) and virtual, such as in a simulator, station-based environments [11].

Many publications analyse the way of driver behaviour in terms of harmful emissions and the level of driving economy [12-16]. In the literature related to driver studies, there are equally broad descriptions of studies performed with participation of people with physical disabilities [17], or mental disorders [18], e.g. Parkinson's disease [19]. One of the important factors determining the driver behaviour is also whether they are under the influence of alcohol or other active substances, such as drugs [20-21].

The driver behaviour tests by many researchers are aimed at determining certain parameters of their behaviour in selected road situations. Tests may be 
carried out on the driver response time [22-24] or the way they undertake defensive manoeuvres [10, 25], as well as on certain indicators facilitating a wider analysis of driver behaviour. Examples of such indicators include headway or time to collision.

There are currently popular studies on influence of various devices on the way the driver reacts, that can directly or indirectly distract them and, at the same time, affect their mode of operation [9-10, 26-27]. These tests concern both the impact of radio, navigation or mobile phone use in various traffic situations [28-31].

Many publications present research aimed at describing the driver behaviour, which in consequence may enable development of relatively simple tools to diagnose the driver profile and their mental inclination to specific, negative behaviours [32]. Important in this regard are studies aimed at understanding the intentions of a driver [33-39].

With reference to the scope of the tests implemented, their analyses may be carried out based on both simple and very complicated methods [40].

Given the complexity of the driver profile, scientists quite often use both simple measurable indicators and more complex ones [41-42]. Quite simple parameters include, for example, vehicle position, its velocity [34, 43] or acceleration [44-47]. There are publications in which the position of control elements is analysed, e.g. the position of accelerator pedal [16, 26, 48] or the service brake. In publication [37], the criteria for assessment of a driver in three types of behaviour were defined: stop, driving and braking. In [49], were classified the operating conditions of vehicles during the urban and extra-urban driving, with simultaneous determination of the traffic jam and dynamic driving.

Author of [50] assesses the acceleration value based on questionnaires. Based on them, three types of city bus rides were defined: comfortable, standard and uncomfortable. In the described tests, the level of uncomfortable longitudinal acceleration was already estimated at $1.5-2.75 \mathrm{~m} / \mathrm{s}^{2}$. The risk analysis of the driver's work during the bus driving is described in detail in [51].

In publication [22], authors proposed a system designed to identify drunk drivers, based on a mobile phone and an acceleration sensor, which assesses drivers by comparing the way in which certain manoeuvres were made with their performance patterns. In [24] and [52] authors developed the concept of a system, which was to determine typical and aggressive drivers based on the Smartphone sensors (accelerometer, gyroscope, magnetometer, GPS, video) for detection, recognition and recording. Use of inertial sensors for similar purposes is described in [15]. Authors in [53] attempt to assess the driver aggressiveness based on the vehicle velocity and position of the accelerator and service brake pedals. In these tests, the vehicle's inertial sensors were used and, using the CAN bus, a driver profile was developed. The authors indicated that braking and passing better characterize the driver's style than the acceleration manoeuvres.

Some behaviour of different drivers during the urban driving was indicated in [54]. The analyses related to emissions showed that the average velocity and deceleration range was lower in the peak hours compared to off-peak hours. As a rule, male drivers used higher acceleration values than women and a higher percentage of driving time in the highest acceleration classes. Women, on the other hand, had a higher percentage of time in the lowest acceleration class. The difference was particularly evident in the residential area. The study showed no major differences in average velocity for both genders, except for one type of street, where men drove faster than women.

This work is part of a larger study to develop a method for parametric assessment of drivers, based on continuous measurement of longitudinal and lateral body accelerations. Values of these accelerations are affected by many factors. In order for them to be used to assess drivers, it is necessary to precisely identify those factors the impact of which on acceleration values and variability is greatest and to "deduct" in some way that impact leaving only the impact of driver's skill, experience, temper and driving technique.

One such factor is certainly the type of car used by a driver. It is known that acceleration on acceleration, deceleration at braking, as well as lateral acceleration during the curvilinear motion of a good-class passenger car with a high-power engine, will be higher (with a sense of comfort for passengers) than, for example, a city bus with some passengers standing. Then the high centre of inertia gives a feeling of discomfort even with relatively low lateral acceleration when cornering, driving on a roundabout, etc.

The second important factor affecting the acceleration values and variability is the road. It can certainly be expected that the same driver, driving the same car, will use different velocities and accelerations, depending on whether he or she is driving on an expressway or an intercity route but of lower class (e.g. single carriageway), or in an urban traffic. This will be affected by factors, such as the number of carriageways, number of lanes on a given carriageway, length of straight sections, traffic organisation and intensity, etc. The impact study of this particular factor is the subject of this work.

\section{Methodology of measurements}

The test route ran from Kielce to Cracow and back and was $110 \mathrm{~km}$ long. During the tests, a number of parameters were measured to assess how the same driver drives the vehicle under different road conditions. The vehicle's route was recorded in detail by the Globtrak $^{\mathrm{TM}}$ system, which allows, among other things, to record the GPS track. The route is shown in Figure 1. 

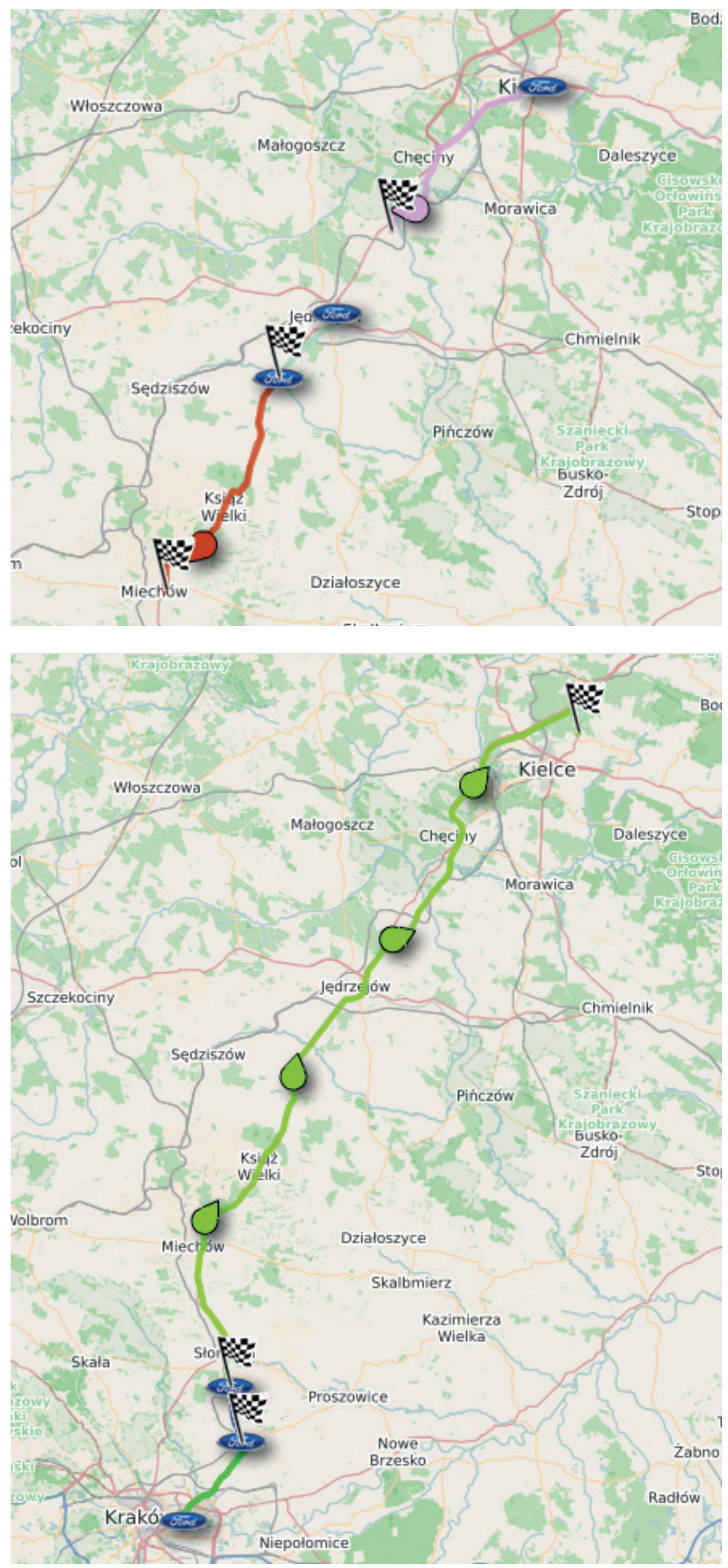

Figure 1 The Kielce-Cracow-Kielce route from the Globtrak ${ }^{\mathrm{TM}}$ system 


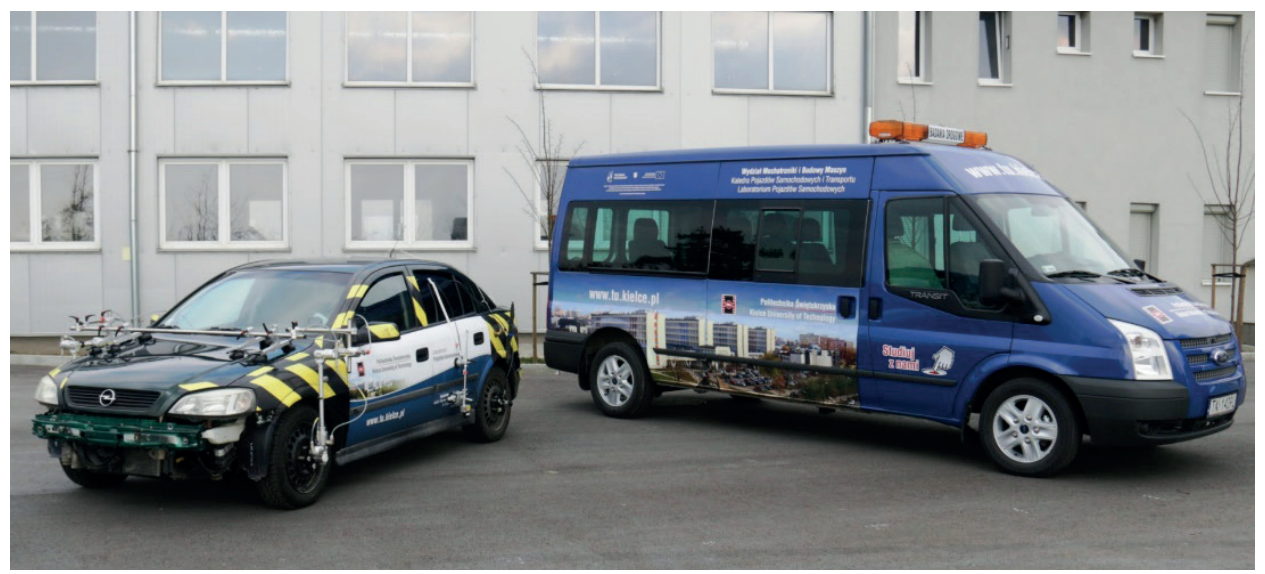

Figure 2 View of the Ford Transit test vehicle

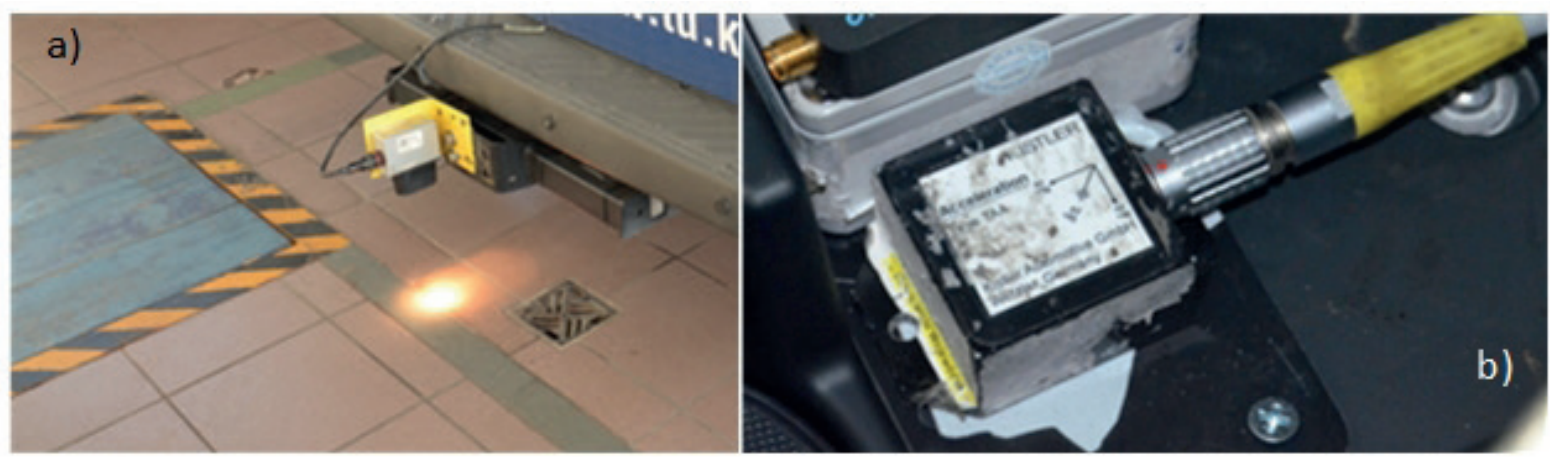

Figure 3 Test apparatus used for testing; a) S-350 Corrsys Datron ${ }^{\circledR}$ optoelectronic sensor, b) Kistler 3 axis TAA linear acceleration sensor
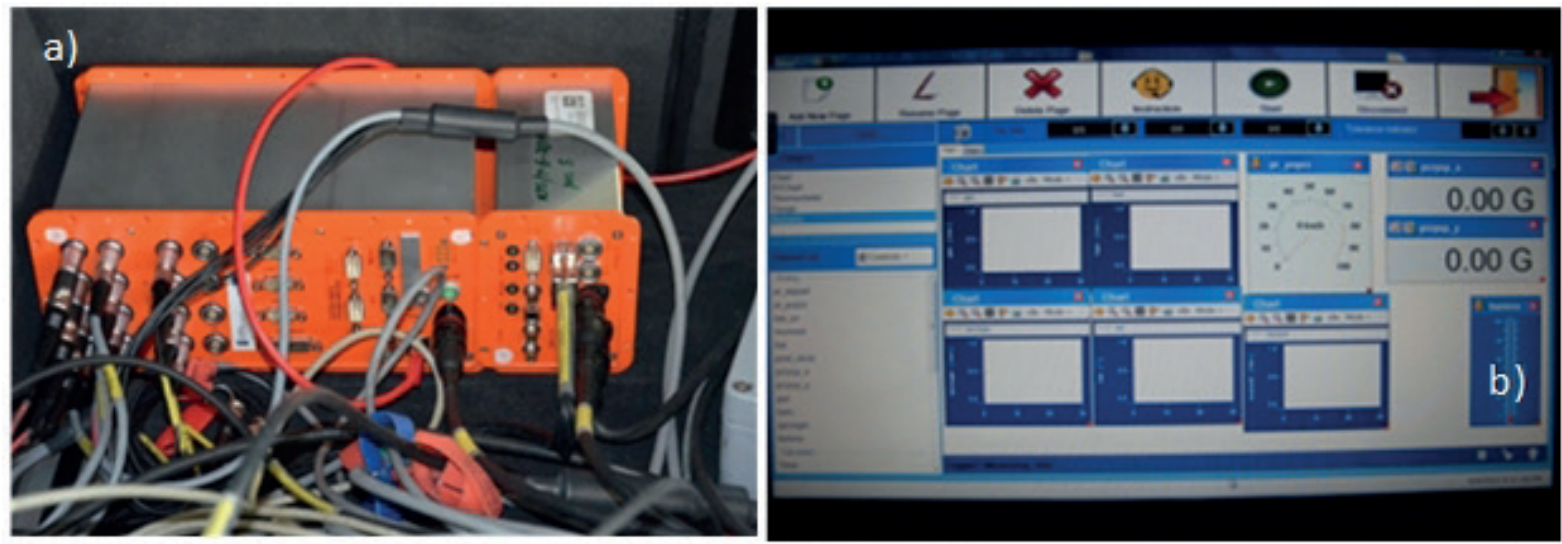

Figure 4 Data acquisition system; a) uEEP 12 Datron ${ }^{\circledR}$ Acquisition Station; b) Control tablet with ARMS® software

The driver behaviour test in the real traffic conditions were performed with Ford Transit test vehicle shown in Figure 2.

The estate Ford Transit (the 4th generation) (9 seats) with complete vehicle kerb weight of $2070 \mathrm{~kg}$ had an engine capacity of $2198 \mathrm{~cm}^{3}$ and the power of $92 \mathrm{~kW}$. It was loaded with a weight of $320 \mathrm{~kg}$.

\section{Measuring equipment characteristics}

To determine the parameters characterizing the route, the test vehicle was equipped by specialist equipment, which included, among others:
- S-350 Corrsys Datron ® optoelectronic sensor designed for measuring the vehicle motion parameters - enabling measurement of longitudinal velocity (up to $250 \mathrm{~km} / \mathrm{h}$ ) and vehicle lateral velocity and torque steer, additionally equipped by a compact display of motion parameters (Figure 3a),

- Kistler ${ }^{\circledR}$ TAA 3-axis linear acceleration sensor (Figure $3 \mathrm{~b}$ ) with a measuring range of $+/-3 \mathrm{~g}$,

- uEEP 12 Datron ${ }^{\circledR}$ data acquisition station (Figure 4a) with control tablet and software (Figure 4b) [55-56]. Due to the need to accurately determine the vehicle motion parameters that were to be used to characterise the driver behaviour, the data was recorded simultaneously at a frequency of $10 \mathrm{~Hz}$. 
Table 1 Vehicle velocity in different driving stages

\begin{tabular}{ccccc}
\hline \multirow{2}{*}{ stage no } & \multicolumn{2}{c}{ speed $(\mathrm{km} / \mathrm{h})$} & \multirow{2}{*}{ travel time $(\mathrm{s})$} \\
\cline { 2 - 4 } 1 & average & maximum & minimum & 1200 \\
2 & 26.4 & 74.4 & 0 & 2800 \\
3 & 89.2 & 130.6 & 20.6 & 1500 \\
4 & 48.5 & 99.0 & 0 & 1900 \\
5 & 16.6 & 67.3 & 0 & 2200 \\
6 & 24.1 & 64.3 & 0 & 2800 \\
7 & 57.9 & 93.7 & 6.3 & 2200 \\
8 & 109.0 & 127.2 & 42.1 & 200 \\
\hline
\end{tabular}
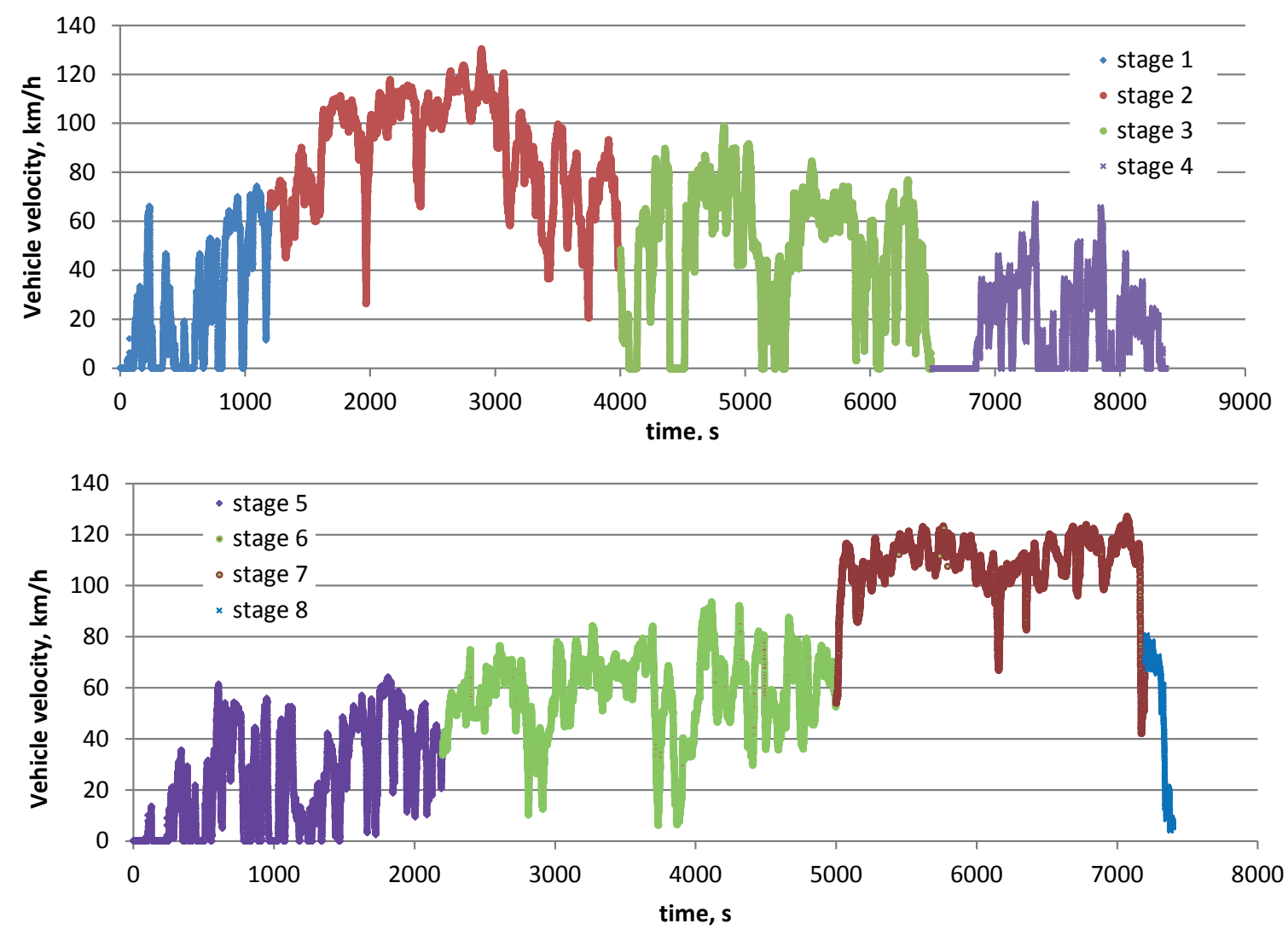

Figure 5 Driving velocity values on the Kielce - Cracow route (stages 1-4), Cracow - Kielce (stages 5-8)

\section{Measurement results}

As a result of measurements, changes in the vehicle's driving parameters were recorded. The section of the analysed route between the cities of Kielce and Cracow was divided into stages, characterised by different traffic conditions.

These conditions applied to:

- $\quad$ Stage 1 - departure from Kielce (urban traffic);

- $\quad$ Stage 2 - expressway (extra-urban drive - fast dual carriageway);

- Stage 3 - driving on the approach road to Cracow (suburban road),

- $\quad$ Stage 4 - driving in Cracow (urban traffic);

- $\quad$ Stage 5 - exit from Cracow (urban traffic);
- Stage 6 - driving on the exit road from Cracow (suburban road);

- $\quad$ Stage 7 - driving of the expressway to Kielce (extraurban drive - fast dual carriageway);

- $\quad$ Stage 8 - driving in Kielce (urban drive);

The vehicle velocities and travel times of the section in each stage are shown in Table 1.

The measured values of the spot velocity, divided into the above presented driving stages, are shown in Figure 5.

The longitudinal acceleration values obtained are summarised in Table 2. Figure 6 shows the recorded longitudinal acceleration values. Positive values refer to acceleration on acceleration and negative values (deceleration) at braking. 
Table 2 Longitudinal acceleration in individual driving stages

\begin{tabular}{ccc}
\hline stage no & maximum $\left(\mathrm{m} / \mathrm{s}^{2}\right)$ & minimum, $\left(\mathrm{m} / \mathrm{s}^{2}\right)$ \\
\hline 1 & 2.33 & -4.19 \\
2 & 2.18 & -2.68 \\
3 & 2.76 & -4.09 \\
4 & 2.15 & -3.37 \\
5 & 2.92 & -3.58 \\
6 & 2.33 & -3.64 \\
7 & 1.39 & -2.85 \\
8 & 1.37 & -1.82 \\
\hline
\end{tabular}
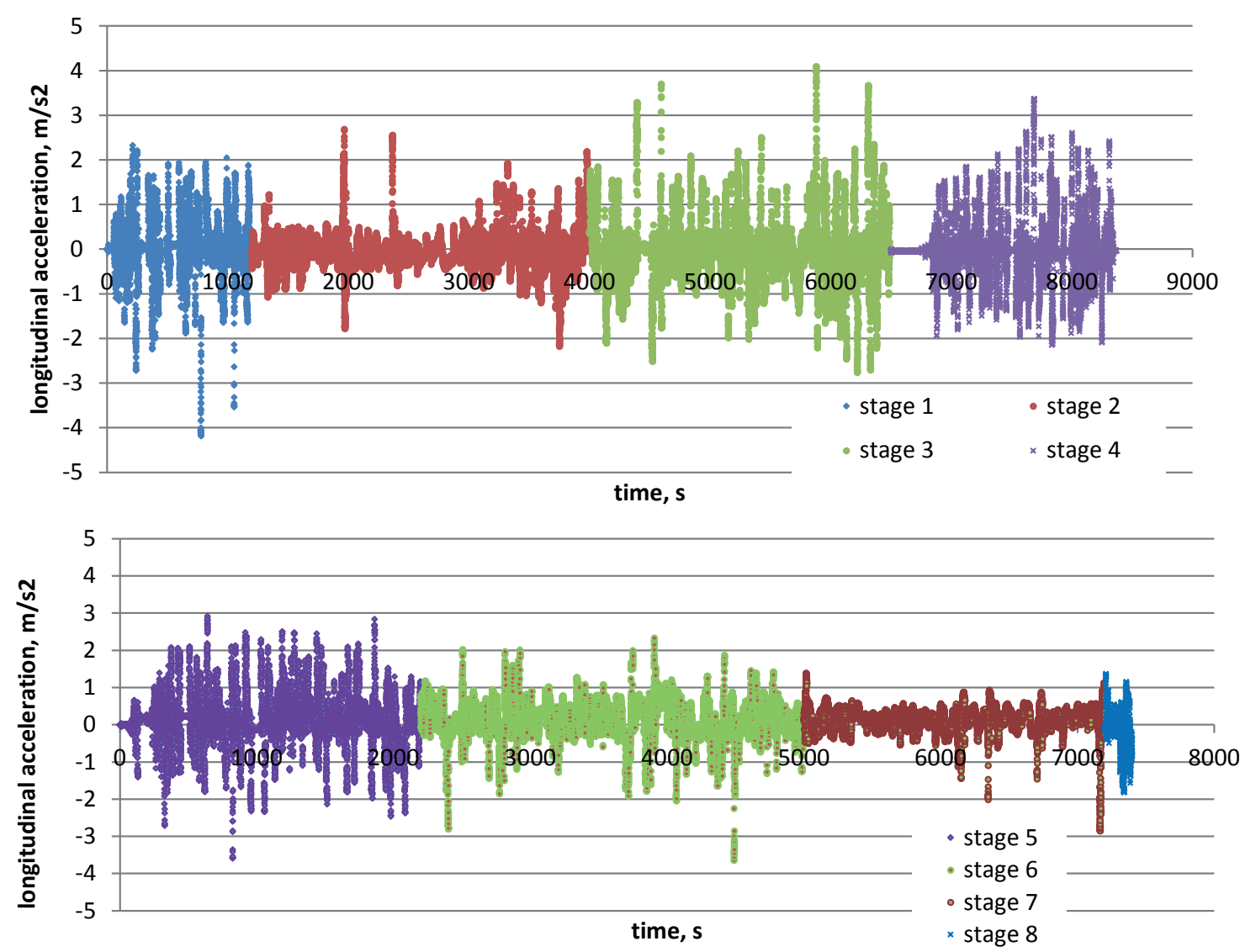

Figure 6 Recorded lateral acceleration values on the Kielce - Cracow route (stages 1-4), Cracow - Kielce (stages 5-8)

Values of the lateral acceleration are summarised in Table 3.

Figure 7 shows the recorded values of lateral acceleration.

\section{Analysis of results}

Figure 8 shows the frequency of particular longitudinal acceleration values on the analysed routes. If one treats the values intended for the entire route as one dataset, it can be assumed that the acceleration values in the range of 0.5 to $-0.5 \mathrm{~m} / \mathrm{s}^{2}$ dominate in the prevailing time of the Kielce - Cracow - Kielce drive, as over $77 \%$. This range was distinguished because it can be conventionally called driving at a constant velocity. During the actual driving at a constant velocity, accelerations also occur depending on e.g. terrain configuration (e.g. downhill and uphill slopes), a gentle increase in velocity by several or more $\mathrm{km} / \mathrm{h}$ to a new higher constant value, etc.

While driving, more than $14-17 \%$ is positive acceleration 0.5 to $3 \mathrm{~m} / \mathrm{s}^{2}$ obtained during acceleration. Positive acceleration values indicating a very intense start above $3 \mathrm{~m} / \mathrm{s}^{2}$ were not recorded, which is an additional confirmation of the "calm" driving style of the tested driver.

In the case of negative accelerations (deceleration during deceleration and braking) values in the range of 0.5 to $-4 \mathrm{~m} / \mathrm{s}^{2}$ were recorded only in nearly $5-8 \%$ of the 
Table 3 Lateral acceleration in individual driving stages

\begin{tabular}{ccc}
\hline stage no & maximum $\left(\mathrm{m} / \mathrm{s}^{2}\right)$ & minimum $\left(\mathrm{m} / \mathrm{s}^{2}\right)$ \\
\hline 1 & 1.78 & -2.71 \\
2 & 2.06 & -2.25 \\
3 & 3.11 & -3.35 \\
4 & 1.78 & -2.79 \\
5 & 1.93 & -3.06 \\
6 & 2.48 & -3.06 \\
7 & 2.23 & -2.34 \\
8 & 1.39 & -2.40 \\
\hline
\end{tabular}
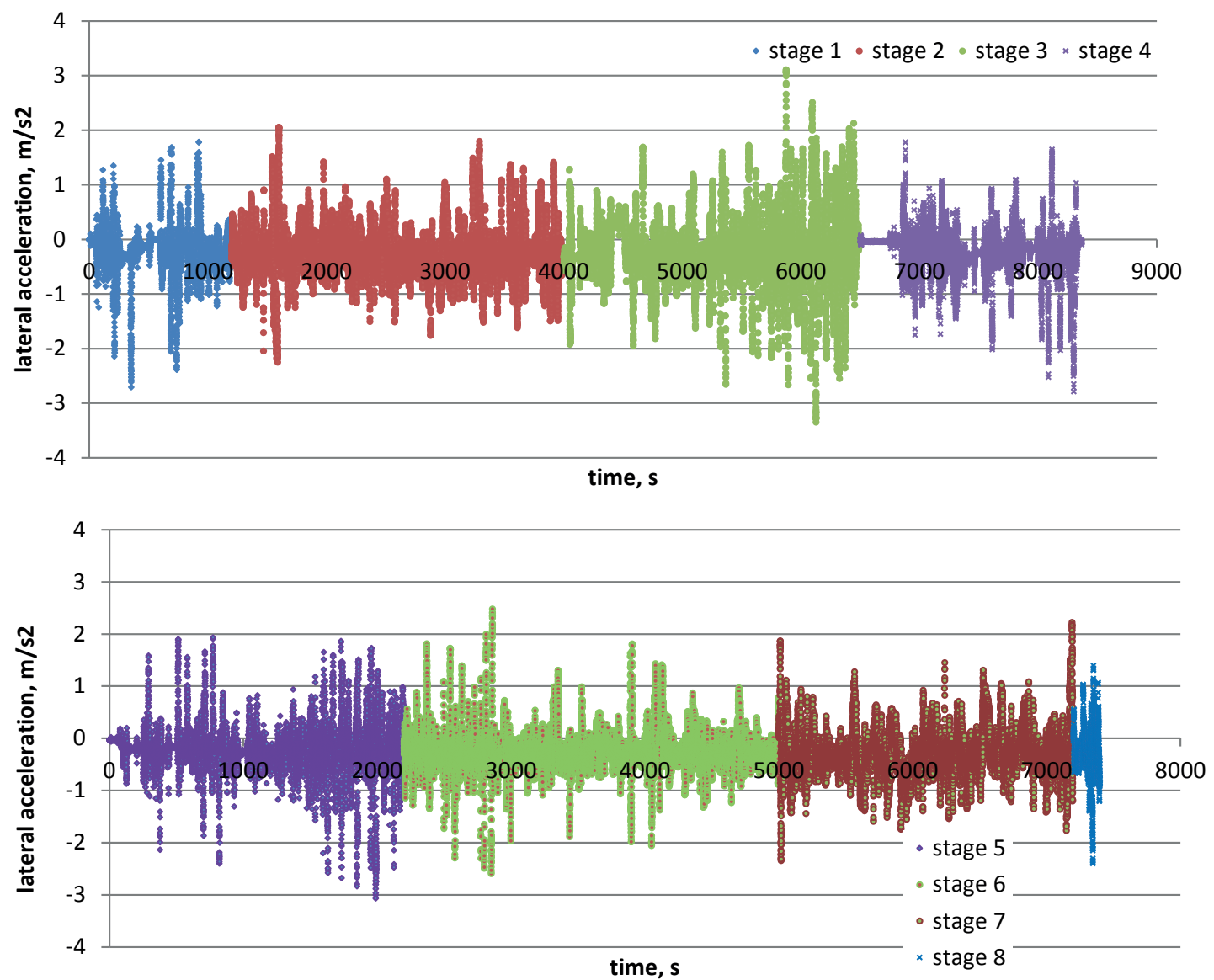

Figure 7 Recorded longitudinal acceleration values on the Kielce - Cracow route (stages 1 -4), Cracow - Kielce (stages 5-8)

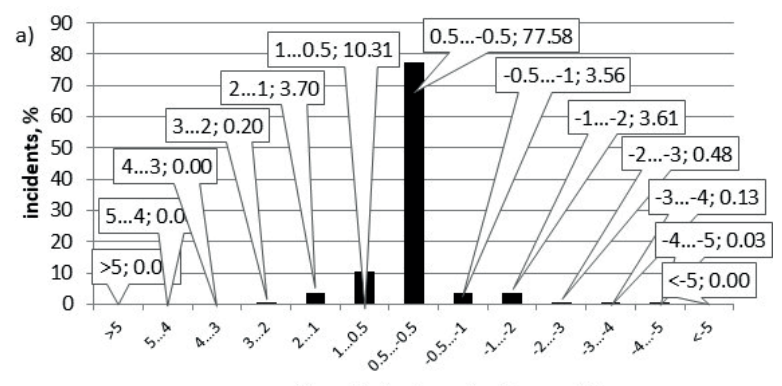

range of longitudinal acceleration, $\mathrm{m} / \mathrm{s} 2$

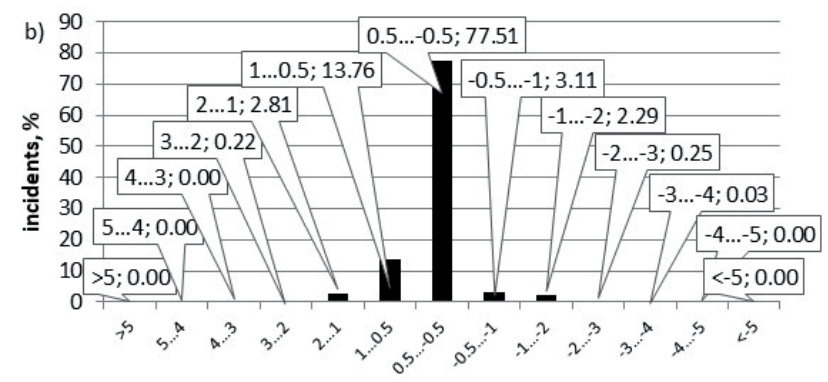

range of longitudinal accceleration, $\mathrm{m} / \mathrm{s} 2$

Figure 8 Frequency of longitudinal acceleration ranges; a) for stages 1 - 4, b) for stages 5 - 8 


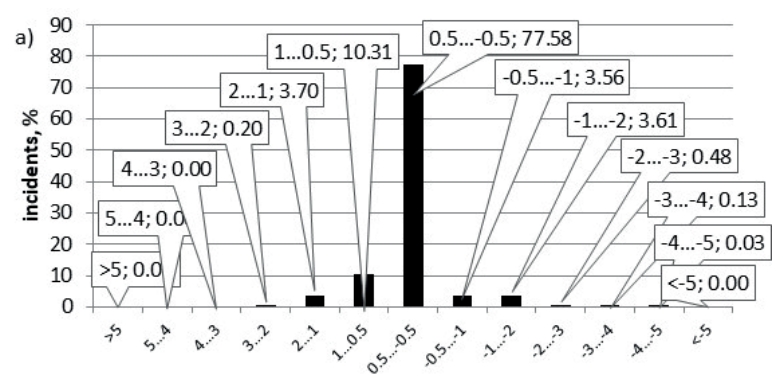

range of longitudinal acceleration, $\mathrm{m} / \mathrm{s} 2$

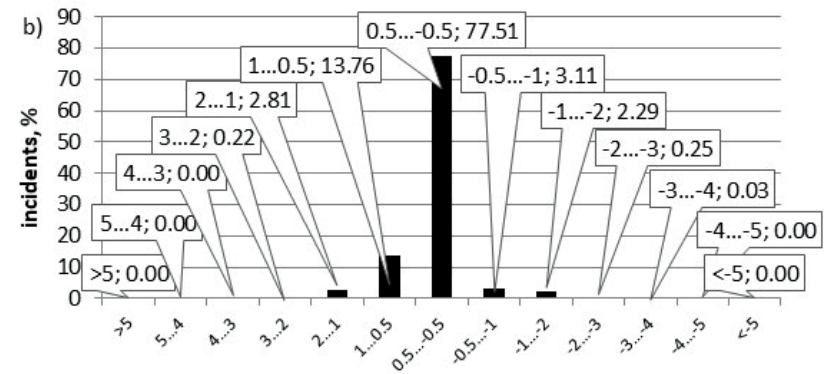

range of longitudinal accceleration, $\mathrm{m} / \mathrm{s} 2$

Figure 8 Frequency of longitudinal acceleration ranges; a) for stages 1 - 4, b) for stages 5 - 8

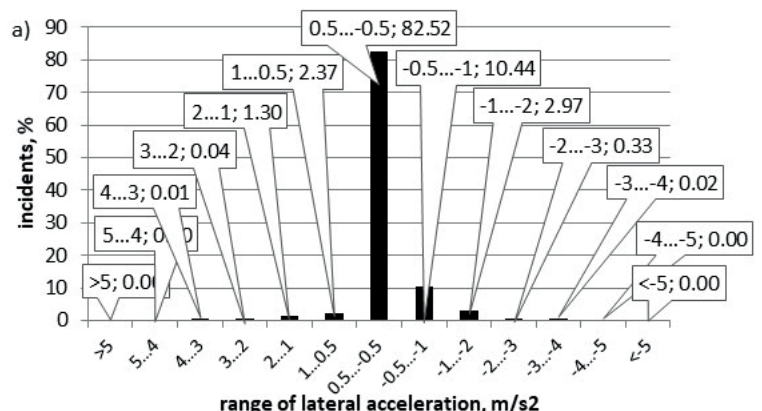

range of lateral acceleration, $\mathrm{m} / \mathrm{s} 2$

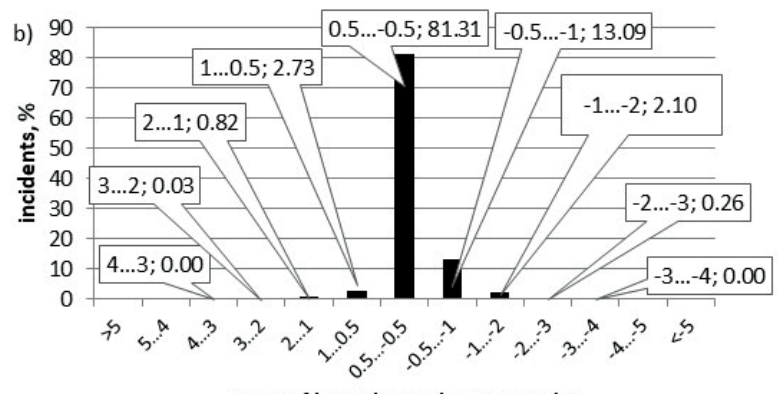

range of lateral accceleration, $\mathrm{m} / \mathrm{s} 2$

Figure 9 Frequency of lateral acceleration ranges: a) for stages 1-4, b) for stages 5 - 8

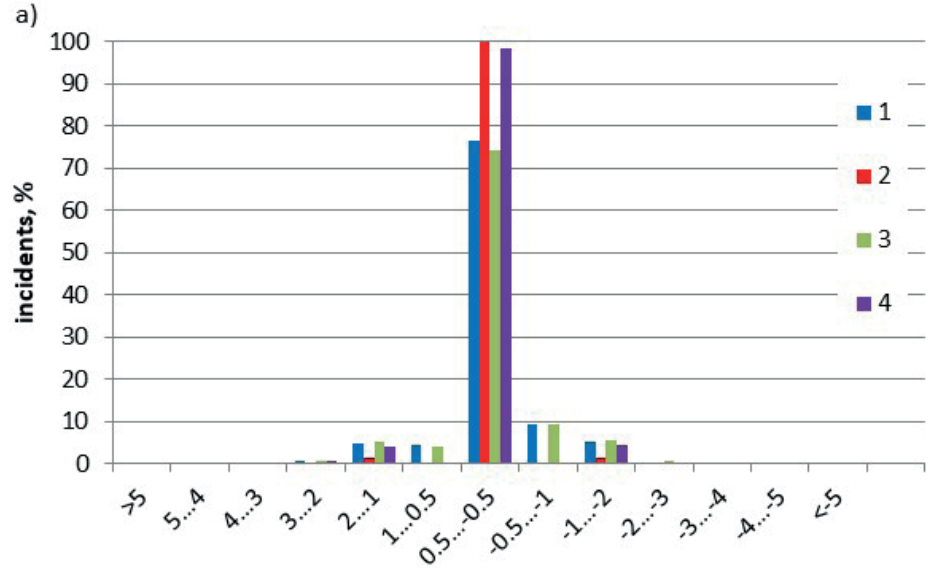

Range of longitudinal acceleration, $\mathrm{m} / \mathrm{s} 2$

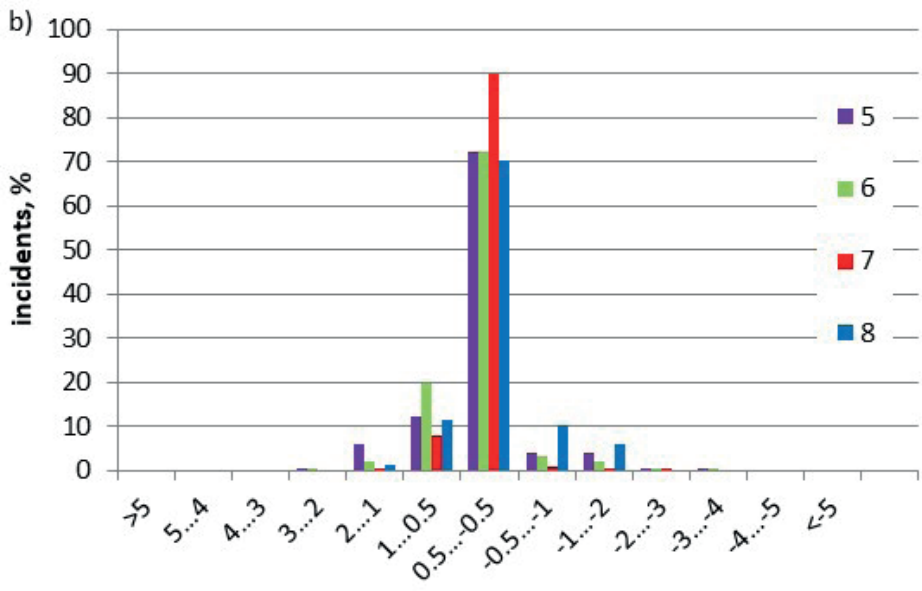

Range of longitudinal acceleration, $\mathrm{m} / \mathrm{s} 2$

Figure 10 Ranges of longitudinal acceleration values in individual stages of the route; a) stages $1-4, b)$ stages 5 - 8 


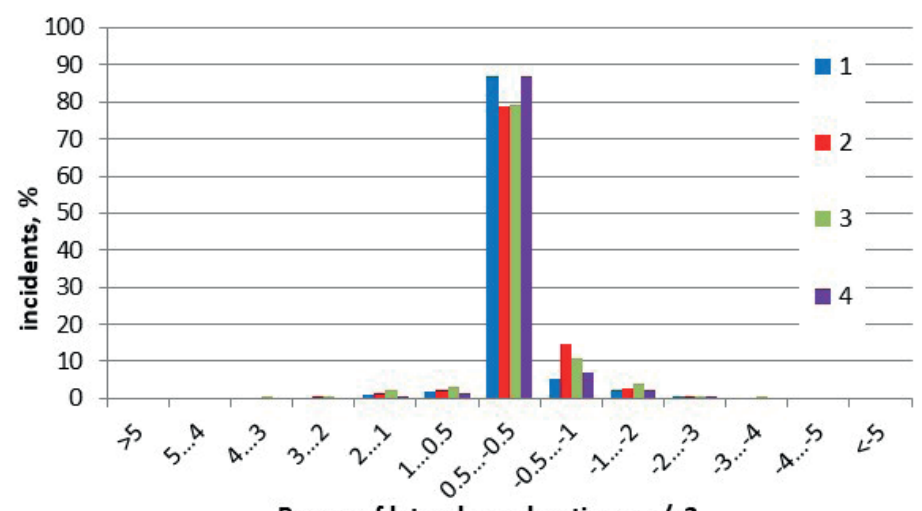

Range of lateral acceleration, $\mathrm{m} / \mathrm{s} 2$

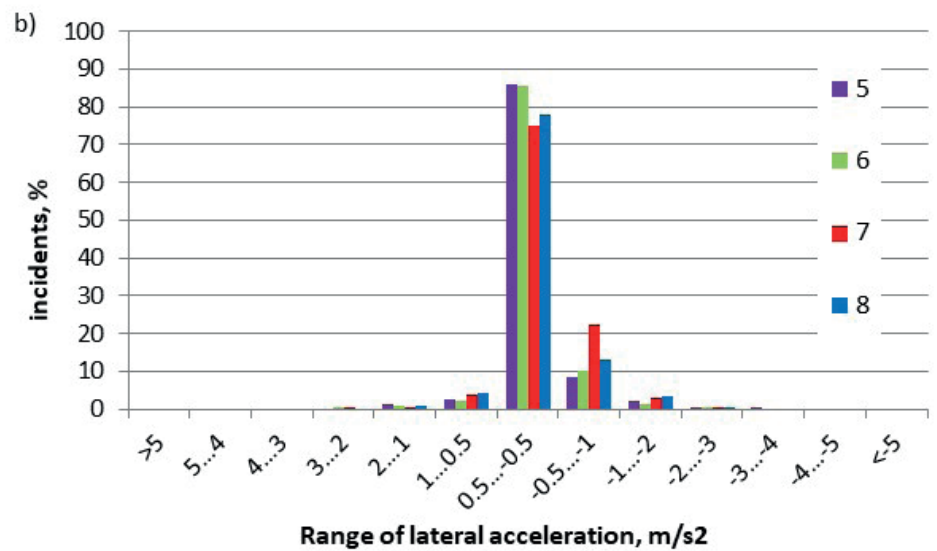

Figure 11 Frequency of the lateral acceleration ranges; a) for stages 1 - 4, b) for stages 5 - 8

a)

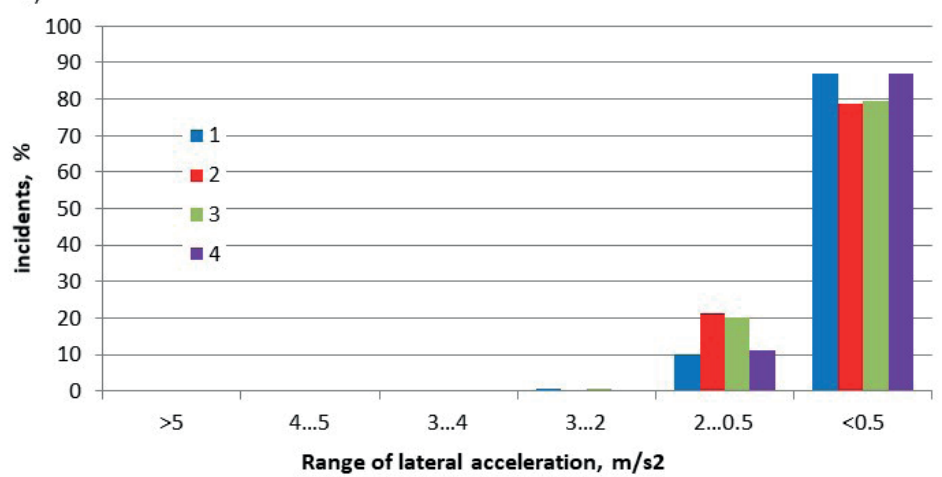

b)

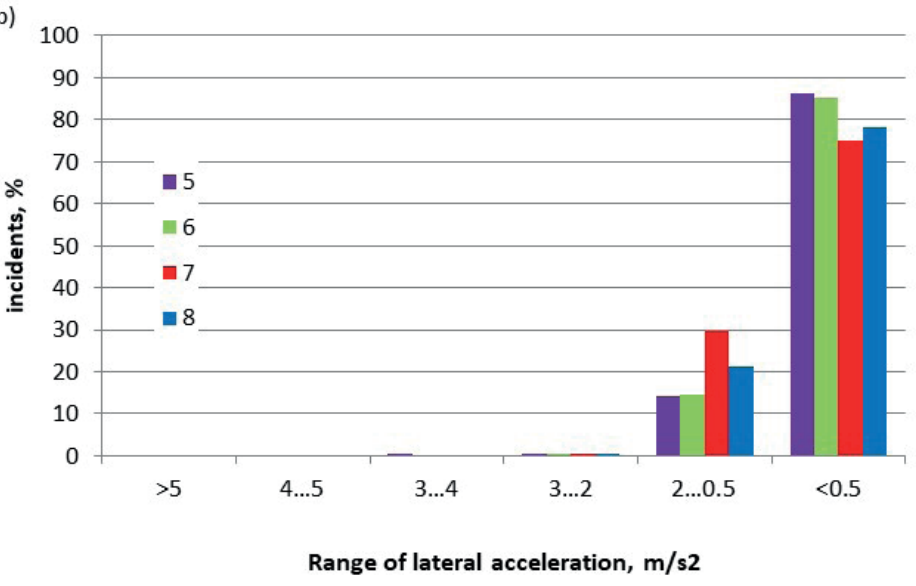

Figure 12 Summary of absolute ranges of the lateral acceleration 
total driving time. Interestingly, there was not a single case in which the deceleration values would exceed $4 \mathrm{~m} /$ $\mathrm{s}^{2}$, i.e. intensive braking. Figure 9 shows the frequency of different lateral acceleration values during driving. Positive and negative values indicate the direction of acceleration. Values in the range -0.5 to $0.5 \mathrm{~m} / \mathrm{s}^{2}$ were recorded in more than $82 \%$ of driving time.

Considering the differences in the way the route is presented in Figure 5 (velocity profiles - very clear velocity differences at individual stages), one may ask the question: what differences will occur when the route is divided into individual stages. Values of longitudinal accelerations along the test section are shown in Figure 10.

As one can see, driving with a longitudinal acceleration range of $-0.5-0.5 \mathrm{~m} / \mathrm{s}^{2}$ took place during the predominant driving time. The highest shares were recorded for the suburban and expressway driving, which means that in such conditions driving is the smoothest. During the urban drive - stage 1 (city of Kielce) and stage 4 (city of Cracow) - very similar shares of the driving time with such acceleration values of $75 \%$ were recorded.

If these ranges are analysed using the lateral acceleration value of $-0.5-0.5 \mathrm{~m} / \mathrm{s}^{2}$ as the value considered to be "normal, smooth drive", an analysis of the frequency of absolute values may be performed. Considering direction of the lateral acceleration, it can be regarded as pointless, since it results from the road route. The absolute values are presented in Figure 12.

\section{Conclusion and summary}

The basic traffic parameters, presented in graphs and tables, show that the road type has a much greater impact on values and variability of the driving velocity than on accelerations, both longitudinal and lateral. Taking as a reference point the lowest average value given in Table $1, \mathrm{v}=16.6 \mathrm{~km} / \mathrm{h}$ (urban traffic - Cracow), the highest value of the average velocity that was recorded in section 7 (expressway) is as much as 6.5 times higher. This is of course the consequence of a very different route and traffic conditions. However, with the same variation in routes and traffic conditions, variation in acceleration is many times lower. The highest acceleration of the car (given in Table 2) is only $113 \%$ higher than the lowest value in the table. The deceleration variation (deceleration during braking, given in the same table) is slightly higher, i.e. $130 \%$, but it is also much less than the velocity variation. In the lateral accelerations, given in Table 3 , a plus or minus symbol indicates a lateral acceleration in the right or left direction, which is due to the route profile and not to the nature of the drive. One can, therefore, merge these values using an absolute value. With this approach, the highest lateral car acceleration (given in Table 3 ) is only
$141 \%$ higher than the lowest value in this table, so the variation of these accelerations is also much lower than the velocity variation.

To sum up this part of the conclusion, it can be stated that values and variability of the driving velocity characterize the type of the road much more than the driving technique of the driver.

In analysis of the longitudinal accelerations, a range from - 0.5 to $0.5 \mathrm{~m} / \mathrm{s}^{2}$ was identified, which the authors, based on the preliminary analysis, conventionally treated as driving at a constant velocity. During the actual driving at a constant velocity, such slight accelerations occur depending on the terrain configuration (e.g. downhill and uphill slopes), a gentle increase in velocity by a few or more $\mathrm{km} / \mathrm{h}$ to a new higher constant value, etc. The share of accelerations from this range, shown in Figure 8, was almost identical for the route in both directions and amounted to about $77.5 \%$ on this route. Figure 10 shows the same distribution of accelerations as in Figure 8, but with the separation of individual sections of different roads. The largest shares of this "calm driving" were, as expected, on the expressway (sections 2 and 7) and amounted to $84 \%$ and $90 \%$, respectively, i.e. deviated from the average $(77.5 \%)$ by $8 \%$ and $16 \%$. It is interesting to note that the share of this "quiet drive" (due to the acceleration criterion) was very similar in the remaining six driving sections and ranged between $70 \%$ and $77 \%$ (see Figure 10).

Values of the positive accelerations above $3 \mathrm{~m} / \mathrm{s}^{2}$, indicating a very intensive start-up, were not recorded. There were also no decelerations exceeding $4 \mathrm{~m} / \mathrm{s}^{2}$, i.e. intensive braking, along the entire route. These two facts and the high proportion of accelerations from -0.5 to $0.5 \mathrm{~m} / \mathrm{s}^{2}$ indicate a "calm" driving style of the tested driver.

In analysis of the lateral accelerations, as in the case of longitudinal accelerations, a range of -0.5 to $0.5 \mathrm{~m} / \mathrm{s}^{2}$ was identified. Based on the preliminary analyses, the authors concluded that these lateral acceleration values testify to smooth cornering and smooth overtaking, passing, or changing lane manoeuvres, which can also be referred to as "calm driving." The share of lateral accelerations from this range shown in Figure 9 was very similar for the route shown in the graph of the route in both directions and was approx. $82.2 \%$ and $81.3 \%$ on this route, i.e. $81.75 \%$ on average for the entire trip. Figures 10 and 11 show the same distribution of accelerations as in Figure 9, but with the separation of individual sections of different roads. The share of this conventional "calm drive"' (due to the lateral acceleration criterion) was very similar in all eight driving sections and ranged between $74.9 \%$ and $87.1 \%$ and deviated from the average value by $-8.4 \%$ and $+6.5 \%$, respectively.

No lateral accelerations of more than $3 \mathrm{~m} / \mathrm{s}^{2}$ were found in seven of the eight sections of the route shown in the graphs. Only on section 3 several cases exceeding this value, but not exceeding $4 \mathrm{~m} / \mathrm{s}^{2}$, were registered. 


\section{Acknowledgements}

The research was carried out as part of the Innovative system research project supporting the motor vehicle insurance risk assessment dedicated to UBI (Usage Based Insurance) No. POIR.04.01.04 00 0004/19 00 financed by the National Centre for Research and Development.

\section{References}

[1] AF WAHLBERG, A. E. Some methodological deficiencies in studies on traffic accident predictors. Accident Analysis and Prevention [online]. 2003, 35(4), p. 473-486. ISSN 0001-4575. Available from: https://doi.org/10.1016/S0001-4575(02)00025-8

[2] HAKAN, A. Driver fatigue and accidents - can visual sensitivity predict drivers ability to drive safely? Proceedings of the Human Factors and Ergonomics Society Annual Meeting [online]. 2000, 44(20), p. 3267-3270. ISSN 2169-5067, eISSN 1071-1813. Available from: https://doi.org/10.1177/154193120004402011

[3] BAUMLER, H. Reaction time in traffic - part I., (in German). Verkehrsunfall und Fahrzeugtechnik. 2007, 11, p. 300-307. ISSN 0724-2050.

[4] BAUMLER, H. Reaction time in traffic - part II., (in German). Verkehrsunfall und Fahrzeugtechnik. 2007, 12, p. 334-340. ISSN 0724-2050.

[5] BAUMLER, H. Reaction time in traffic - part III. (in German). Verkehrsunfall und Fahrzeugtechnik. 2008, 1, p. 22-27. ISSN 0724-2050.

[6] GREEN, M. How long does it take to stop? Methodological analysis of driver perception-brake times. Transportation Human Factors [online]. 2000, 2(3), p. 195-216. ISSN 1093-9741. Available from: https://doi.org/10.1207/STHF0203_1

[7] TORNROS, J. Effect of driving speed on reaction time during motorway driving, Accident Analysis and Prevention [online]. 1995, 27(4), pp. 435-442. ISSN 0001-4575. Available from: https://doi.org/10.1016/0001- 4575(94)00084-Y

[8] AHLSTROM, C., ANUND, A., FORS, C., ÅKERSTEDT, T. The effect of daylight versus darkness on driver sleepiness: a driving simulator study. Journal of Sleep Research [online]. 2018, 27(3), e12642. eISSN 1365-2869. Available from: https://doi.org/10.1111/jsr.12642

[9] DI MILIA, L., KECKLUND, G. The distribution of sleepiness, sleep and work hours during a long distance morning trip: a comparison between night-and non-night workers. Accident Analysis and Prevention [online]. 2013, 53, p. 17-22 ISSN 0001-4575. Available from: https://doi.org/10.1016/j.aap.2013.01.003

[10] JURECKI, R. Influence of the scenario complexity and the lighting conditions on the driver behaviour in a carfollowing situation. The Archives of Automotive Engineering - Archiwum Motoryzacji [online]. 2019, 83(1), p. 151-173. eISSN 2084-476X. Available from: https://doi.org/10.14669/AM.VOL83.ART11

[11] GUZEK, M. Simplex and complex reaction time of male drivers in various age - results of research with use of reflexometer. The Archives of Automotive Engineering - Archiwum Motoryzacji. 2014, 65(3), p. 19-28. eISSN 2084-476X.

[12] ANDRZEJEWSKI, M., NOWAK, M. The influence of the driving style according to the principles of ecodriving on the emission of toxic substances from a light utility vehicle. Autobusy - Technika, Eksploatacja, Systemy Transportowe [online]. 2019, 24(6), p. 33-37. ISSN 1509-5878, eISSN 2450-7725. Available from: https://doi.org/10.24136/atest.2019.121

[13] BIELACZYC, P., PAJDOWSKI, P., SZCZOTKA, A. Analysis of the impact of drivers' driving styles on emissions and fuel consumption. Czasopismo Techniczne. Mechanika. 2004, 101, p. 87-94. ISSN 1897-6301.

[14] SZCZOTKA, A., PUCHALKA, B., BIELACZYC, P. Impact of driver's driving style on the uncertainty of emissions measurements on a chassis dynamometer. Autobusy - Technika, Eksploatacja, Systemy Transportowe. 2018, 226(12), p. 675-679. ISSN 1509-5878, eISSN 2450-7725.

[15] VAN LY, M., MARTIN, S., TRIVEDI, M. M. Driver classification and driving style recognition using inertial. In: 2013 IEEE Intelligent Vehicle Vehicles Symposium (IV): proceedings [online]. IEEE. 2013. ISSN 1931-0587, p. 1040-1045, Available from: https://doi.org/10.1109/IVS.2013.6629603

[16] VARHELYI, A., HJALMDAHL, M., HYDEN, C., DRASKOCZY, M. Effects of an active accelerator pedal on driver behaviour and traffic safety after long-term use in urban areas. Accident Analysis and Prevention [online]. 2004, 36(5), p. 729-737. ISSN 0001-4575. Available from: https://doi.org/10.1016/j.aap.2003.06.001

[17] SPALDING, T. J. W., KISS, J., KYBERD, P., TURNER-SMITH, A., SIMPSON, A. H. Driver reaction time after total knee replacement. The Journal of Bone and Join Surgery [online]. 1994, 8(76-B), p. 754-756. ISSN 2049-4394, eISSN 2049-4408. Available from: https://doi.org/10.1302/0301-620X.76B5.8083265

[18] MITAS, A., BUGDOL, M., RYGULA, A. The psychophysiological conditionings of driver's work under the aspect of traffic safety. Transport Problems [online]. 2009, 4(1), p. 87-94. ISSN 1896-0596, eISSN 2300-861X. 
[19] MADELEY, P., HULlEY, J.L., WILDGUST, H., MINDHAM, R. H. Parkinson's disease and driving ability. Neurol Neurosurg Psychiatry [online]. 1990, 53(7), p. 580-582. ISSN 0022-3050, eISSN 1468-330X. Available from: https://doi.org/10.1136/jnnp.53.7.580

[20] HINDMARCH, I. Psychomotor function and psychoactive drugs. British Journal of Clinical Pharmacology [online]. 2004, 58(7), p. 189-209. eISSN 1365-2125. Available from: https://doi.org/10.1111/j.1365-2125.2004.02279.x

[21] OGDEN, J. D., MOSKOWITZ, H. Effects of alcohol and other drugs on driver performance. Traffic Injury Prevention [online]. 2004, 5(3), p. 185-198. ISSN 1538-9588, eISSN 1538-957X. Available from: https://doi.org/10.1080/15389580490465201

[22] BENDERIUS, O., MARKKULA, G., WOLFF, K., WAHDE, M. Driver behaviour in unexpected critical events and in repeated exposures - a comparison. European Transport Research Review [online]. 2014, 6(1), p. 51-60. ISSN 1866-8887. Available from: https://doi.org/10.1007/s12544-013-0108-y

[23] JURECKI, R., STANCZYK, T. L. Driver model for the analysis of pre-accident situations. Vehicle System Dynamics [online]. 2009, 47(5), p. 589-612. ISSN 0042-3114, eISSN 1744-5159. Available from: https://doi.org/10.1080/00423110802276028

[24] JURECKI R., STANCZYK T. Driver reaction time to lateral entering pedestrian in a simulated crash traffic situation. Transportation Research Part F, Traffic Psychology and Behavior [online], 2014, 27, p. 22-36. ISSN 1369-8478. Available from: https://doi.org/10.1016/j.trf.2014.08.006

[25] KAYSI, I. A., ABBANY, A. S. Modeling aggressive driver behavior at unsignalized intersections. Accident Analysis and Prevention [online]. 2007, 39(4), p. 671-678. ISSN 0001-4575. Available from: https://doi.org/10.1016/j.aap.2006.10.013

[26] AUGUSTYNOWICZ, A. Recognition of driver intentions based on analysis of the instantaneous position of the accelerator pedal. In: International Automotive Conference Konmot-Autoprogres: proceedings. Vol. 1. Motor Vehicles. 2004. p. 59-66.

[27] KRUSZEWSKI, M. Methods of assessing distraction of inexperienced drivers using fuzzy logic (in Polish). $\mathrm{Ph} . \mathrm{D}$. thesis. Warsaw: Politechnika Warszawska, 2019.

[28] AMADO, S., ULUPINAR, P. The effects of conversation on attention and peripheral detection: is talking with a passenger and talking on the cell phone different? Transportation Research Part F: Traffic Psychology and Behaviour [online]. 2005, 8(6), p. 383-395. ISSN 1369-8478. Available from: https://doi.org/10.1016/j. trf.2005.05.001

[29] DAI, J., TENG, J., BAI, X., SHEN, Z., XUAN, D. Mobile phone based drunk driving detection. In: 4th International Conference on Pervasive Computing Technologies for Healthcare: proceedings [online]. IEEE. 2010. ISBN 978-963-9799-89-9, p. 1-8. Available from: https://doi.org/10.4108/ICST.PERVASIVEHEALTH2010.8901

[30] MOHEBBI, R., GRAY, R., TAN, H. Z. Driver reaction time to tactile and auditory rear-end collision warnings while talking on a cell phone. Human Factors [online]. 2009, 51(1), p. 102-110. ISSN 1093-9741. Available from: https://doi.org/10.1177/00187208 09333517

[31] NILSSON, L., ALM, H. Effects of mobile telephone use on elderly drivers' behaviour including comparisons to young drivers behaviour [online]. Linkoping: Statens Vag - och Trafikinstitut., VTI sartryck 176, 1991. ISSN 1102-626X. Available: http://www.diva-portal.org/smash/record.jsf?pid=diva2\%3A672100\&dswid=9029

[32] BARTECKI, K., AUGUSTYNOWICZ, A. Use of a partially recurrant neural network to classify the driver's driving style. In: Process and system diagnostics / Diagnostyka procesow $i$ systemow (in Polish). KORBICZA, J., PATANA, K., KOWALA, M. (eds.). Warszawa: Akademicka Oficyna Wydawnicza EXIT, 2007. ISBN 978-83-60434-31-4. p. 417-424.

[33] FRENCH, D. J., WEST, R. J., ELANDER, J. WILDING, J. M. Decision-making style, driving style and selfreported involvement in road traffic accidents. Ergonomics [online]. 1993, 36(6), p. 627-644. ISSN 0014-0139, eISSN 1366-5847. Available from: https://doi.org/10.1080/00140139308967925

[34] MERKISZ, J., PIELECHA, J., PIELECHA, I. Impact of driver style of driving on the environmental performance of the vehicle. Logistyka, 2, 2010, p. 1910-1920. ISSN 1231-5478.

[35] MIERLO, J., MAGGETTO,, G., BURGWAL, E., GENSE, R. Driving style and traffic measures - influence on vehicle emissions and fuel consumption. Proceedings of the Institution of Mechanical Engineers, Part D, Journal of Automobile Engineering [online]. 2004, 218(1), p. 43-50. ISSN 0954-4070, eISSN 2041-2991. Available from: https://doi.org/10.1243/095440704322829155

[36] RYGULA, A., Driving style identification method based on speed graph analysis. In: 4th International Conference on Image Analysis and Biometrics and International Conference on Kansei Engineering and Affective Systems: proceedings [online]. 2009. ISBN 978-0-7695-3692-7. Available from: https://doi.org/10.1109/ICBAKE.2009.51

[37] SMOLEN, P., STAROWICZ, W. The concept of a driver's driving style assesing system in road freight transport. Transport Miejski i Regionalny. 2018, 8, p. 18-23. ISSN 1732-5153.

[38]VAN MIERLO, J., MAGGETTO, G., VAN DE BURGWAL, E., GENSE, R. Driving style and traffic measures-influence on vehicle emissions and fuel consumption. Proceedings of the Institution of Mechanical 
Engineers, Part D: Journal of Automobile Engineering [online]. 2004, 218(1), p. 43-50. ISSN 0954-4070, eISSN 2041-2991. Available from: https://doi.org/10.1243/095440704322829155

[39] GUIHE, Q., YULONG, L., MINGKUI, N., ANLIN, G., YISONG, D. Estimation of road situations and driver's intention in automotive electronic control system. In: International Vehicle Electronics Conference: proceedings. IEEE. 1999. p. 199-201.

[40] AUGUSTYNOWICZ, A., BROL, S. Use of continuous wavelet transform for estimating the driver profile in urban traffic conditions. The Archives of Automotive Engineering - Archiwum Motoryzacji. 2007, 4, p. 293-307. eISSN 2084-476X.

[41] MERKISZ J., ORSZULAK, B. Initial analysis of the driver's driving style parameters recording. Logistyka. 2015, 3, p. 3210-3214. ISSN 1231-5478.

[42] WANG, J., LU, M., LI, K. Characterization of longitudinal driving behavior by measurable parameters. Transportation Research Record [online]. 2010, 2185(1), p. 15-23. ISSN 0361-1981, eISSN 2169-4052. Available from: https://doi.org/10.3141/2185-03

[43] LAJUNEN, T., KAROLA, J., SUMMALA, H. Speed and acceleration as measures of driving style in young male drivers. Perceptual and Motor Skills [online]. 1997, 85(1), p. 3-16. ISSN 0031-5125, eISSN 1558-688X. Available from: https://doi.org/10.2466/pms.1997.85.1.3

[44] AF WAHLBERG, A. E. The relation of acceleration force to traffic accident frequency: a pilot study. Transportation Research Part F: Traffic Psychology and Behaviour [online]. 2000, 3, p. 29-38. ISSN 1369-8478. Available from: https://doi.org/10.1016/S1369-8478(00)00012-7

[45] MERKISZ, J., PIELECHA, J., TARKOWSKI, S. On-board recorders of traffic parameters and their application to assess comfort in city buses. Autobusy - Technika, Eksploatacja, Systemy Transportowe. 2012, 13, p. 300-305. ISSN 1509-5878, eISSN 2450-7725.

[46] REYMOND, G., KEMENY, A., DROULEZ, J., BERTHOZ, A. Role of lateral acceleration in curve driving: Driver model and experiments on a real vehicle and a driving simulator. Human Factors [online]. 2001, 43(3), p. 483-495, ISSN 1093-9741. Available from: https://doi.org/10.1518/001872001775898188

[47] TAKAHASHI, H., KURODA, K. A study on mental model for inferring driver's intention. In: 35th IEEE Conference - Decision and Control: proceedings [online]. IEEE. 1996. ISBN 0-7803-3590-2. Available from: https://doi.org/10.1109/CDC.1996.572826

[48] HJALMDAHL, M., VARHELYI, A. Speed regulation by in-car active accelerator pedal: effects on driver behavior. Transportation Research Part F, Traffic Psychology and Behavior [online]. 2004, 7(2), p. 77-94. ISSN 1369-8478. Available from: https://doi.org/10.1016/j.trf.2004.02.002

[49] KROPIWNICKI, J. Classification of vehicle operating conditions using the proportion of engine idling time. Autobusy - Technika, Eksploatacja, Systemy Transportowe. 2011, 12, p. 204-209. ISSN 1509-5878, eISSN 2450-7725.

[50] MERKISZ, J., TARKOWSKI, S. Dynamic factors and their impact on the subjective sense of comfort in city buses. Postepy Nauki i Techniki. 2012, 14, p. 169-178. ISSN 2080-4075.

[51] WOJTYTO, D., RYDZ, D. Risk assessment for the task in the context of the bus driver's work process. Autobusy - Technika, Eksploatacja, Systemy Transportowe [online]. 2018, 220(6), p. 1284-1288. ISSN 1509-5878, eISSN 2450-7725. Available from: https://doi.org/10.24136/atest.2018

[52] JOHNSON, D. A., TRIVEDI, M. M. Driving style recognition using a smartphone as a sensor platform. In: 14th International IEEE Conference on Intelligent Transportation Systems ITSC: proceedings [online]. IEEE. 2011. p. 1609-1615. Available from: https://doi.org/10.1109/ITSC.2011.6083078

[53] KUDZIA, K., STOPA, S. Algorithm to determine the cost-effectiveness of a driving style based on data from car diagnostic systems. Logistyka. 2015, 4, p. 4320-4326. ISSN 1231-5478.

[54] ERICSSON, E. Variability in urban driving patterns. Transportation Research Part D: Transport and Environment. 2000, 5(5), p. 337-354. ISSN 1361-9209. Available from: https://doi.org/10.1016/S1361-9209(00)00003-1

[55] JURECKI, R., STANCZYK, T. L. Analyzing driver response times for pedestrian intrusions in crash-imminent situations. In: 11th International Scientific and Technical Conference on Automotive Safety: proceedings [online]. 2018. p. 1-7, Available from: https://doi.org/10.1109/AUTOSAFE.2018.8373339

[56] JURECKI R., STANCZYK T., JASKIEWICZ M. Driver's reaction time in a simulated, complex road incident. Transport [online]. 2017, 32(1), p. 44-54. ISSN 1648-4142, eISSN 1648-3480. Available from: https://doi.org/10.3 $846 / 16484142.2014 .913535$ 